\title{
Evaluation of Toxoplasma gondii, Rubella virus and Cytomegalovirus Infections
}

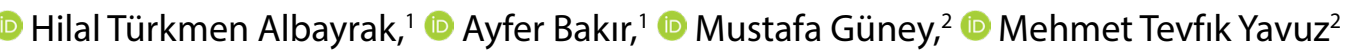 \\ 'Department of Medical Microbiology, University of Health Sciences, Gulhane Training and Research Hospital, \\ Ankara, Turkey \\ ${ }^{2}$ Department of Medical Microbiology, University of Health Sciences, Gülhane Faculty of Medicine, Ankara, Turkey
}

\section{ABSTRACT}

Objectives: Primary infection agents occurring during pregnancy and causing congenital anomalies are Toxoplasma gondii (T.gondii), rubella virus and cytomegalovirus (CMV). It was revealed that these agents infected the fetus by crossing the placenta and increased the rate of fetal morbidity and mortality. This study aimed to investigate the relationship between seroprevalences of T. gondii, rubella virus and CMV antibodies.

Methods: The results were retrospectively evaluated. Pregnant women's serum samples sent to the Medical Microbiology Laboratory of Ankara Gülhane Training and Research Hospital between January 2018 and December 2018 were included in this study. T. gondii, rubella virus and CMV IgM and IgG antibodies were analysed using the chemiluminescent immunoassay method.

Results: In this study, the results of 647 pregnant patients were retrospectively analysed. The median age of the attendants was $28.0(18.0-49.0)$ years. IgM positivities for T. gondii, rubella virus and CMV were found as 3

Please cite this article as: Türkmen Albayrak H, Bakır A, Güney M, Yavuz MT. Evaluation of Toxoplasma gondii, Rubella virus and Cytomegalovirus Infections. Anatol J Family Med 2020;3(2):136-140.

Address for correspondence: Dr. Hilal Türkmen Albayrak. Department of Medical Microbiology, University of Health Sciences, Gulhane Training and Research Hospital, Ankara, Turkey

Phone: +90 5058145869

E-mail:

hilal.turkmen@hotmail.com

Received Date: 03.09.2019

Accepted Date: 15.04.2020

Published online: 21.08 .2020

@Copyright 2020 by Anatolian Journal of Family Medicine -

Available online at WWW.anatoljfm.org

OPEN ACCESS

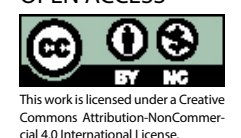
$(0.6 \%), 3(0.5 \%)$ and $61(15.0 \%)$ respectively and IgG positivities were $66(13.8 \%), 529(91.7 \%)$ and $394(99.3 \%)$, respectively.

Conclusion: In this study, the results were consistent with the findings obtained in the regional studies. Seroprevalence studies in pregnant women will be guide for the necessity of prenatal screening tests. Therefore, the findings suggest that pregnant women and women of childbearing age should be investigated concerning $T$. gondii, the rubella virus and CMV antibodies.

Keywords: Toxoplasmosis; rubella; cytomegalovirus; pregnant woman.

\section{INTRODUCTION}

Toxoplasma gondii (T. gondii), rubella virus, cytomegalovirus (CMV) are the most common causes of congenital infections around the world. ${ }^{[1]}$ While these agents cause asymptomatic or mild infections in pregnant women, primary infections occurring due to the agents crossing the placenta barrier in early pregnancy may cause congenital malformations, intrauterine growth retardation, spontaneous abortions, premature birth and fetal death. ${ }^{[2]}$ Infection intensity depends on the age of pregnancy, virulence of the organism, and the severity of placental damage and maternal disease during the infection ${ }^{[3]}$ Infections related to these agents are the causes of morbidity and mortality especially in developing countries. ${ }^{[2]}$

T. gondii is a protozoan parasite spread by eating cat feces or contaminated soil or undercooked meat. Tropical regions in the world have the highest prevalence rate. ${ }^{[4]}$ It is reported that fetal infection risk after infection is higher than $15 \%$ if she is infected in the 13 th week 
and higher than $70 \%$ if she is infected in the 36th week of the pregnancy. ${ }^{[5]}$

In primary infection caused by rubella virus in the first trimester, the risk for congenital rubella virus is the highest with a rate of $80-100 \%$. This rate decreases to $10-20 \%$ in the second trimester while it increases again to $60 \%$ in the third trimester. ${ }^{[5]}$

CMV is the most common congenital viral infection agent in approximately $0.4-2.3 \%$ of live births ${ }^{[6]}$ While primary infection risk after vertical transmission is between $30 \%$ and $40 \%$, this risk increases as the age of pregnancy increases, however, serious infections are observed in the early pregnancy infections. ${ }^{[6,7]}$

Prevalence of $T$. gondii, rubella virus and CMV infections differs according to the geographical regions. Data on serological conditions of the pregnant women regarding congenital infection agents provide information about the prevention of congenital infections based on these agents in women at risk. ${ }^{[8]}$ It is hard to diagnose the infection with clinical findings because the infections in pregnancy are generally inapparent and asymptomatic. Therefore, the diagnosis is established by monitoring specific IgM antibodies or seroconversion in double serum sample. ${ }^{[9]}$

There are regional seroprevalence studies related to the seropositivity of these infections in Turkey. This study aimed to evaluate the seroprevalences of T.gondii, rubella virus and $C M V$ infections in pregnant women presenting to our hospital and obtain regional epidemiological data.

\section{METHOD}

Pregnant women between the ages of 18 and 49 presenting to Gülhane Education and Research Hospital at the University of Health Sciences between January 2018 and December 2018 were included in this retrospective study. In serum samples sent with the diagnosis of pregnancy to the Medical Microbiology Virology Laboratory, T. gondii, rubella virus and CMV IgM and IgG antibodies were analysed by IgM and IgG commercial kits (Abbott, USA) with chemiluminescent microparticular enzyme immunoassay method in Architect system (Architect i2000SR, Abbott Diagnostics, USA). The results were evaluated according to the evaluation criteria of the kits. Index values according to the commercial kit were accepted as following: index value of $<0.5 \mathrm{IU} / \mathrm{mL}$ is negative and $\geq 0.6 \mathrm{IU} / \mathrm{mL}$ is positive for T.gondii IgM, value of $<1.6 \mathrm{IU} / \mathrm{mL}$ is negative and $\geq 3.0$ $\mathrm{IU} / \mathrm{mL}$ is positive for T.gondii IgG; index value of $<1.2 \mathrm{IU} / \mathrm{mL}$ is negative and $\geq 1.6 \mathrm{IU} / \mathrm{mL}$ is positive for rubella virus $\mathrm{IgM}$, value of $<5 \mathrm{IU} / \mathrm{mL}$ is negative and $\geq 10 \mathrm{IU} / \mathrm{mL}$ index value of $<0.85 \mathrm{IU} / \mathrm{mL}$ is negative and $\geq 1.0 \mathrm{IU} / \mathrm{mL}$ is positive for CMV $\operatorname{lgM}$, value of $\geq 6 \mathrm{AU} / \mathrm{mL}$ is positive for CMV IgG.

\section{Statistical Analysis}

Based on the data collected in the study, SPSS 15 software (SPSS Inc, Chicago, IL, USA) was used for statistical evaluation. Frequency, percentage, median, minimum and maximum values were used from the descriptive statistics methods.

\section{RESULTS}

In this study, the results of $479(74.0 \%)$ pregnant women for T. gondii IgM and IgG antibodies, 590 (91.2\%) for rubella virus IgM and IgG antibodies and 407 (62.9\%) for CMV IgM and IgG antibodies (647 pregnant women in total) were retrospectively evaluated. Median age of the attendants was 28.0 (18.0-49.0) years. IgM positivities for T. gondii, rubella virus and CMV were $3(0.6 \%), 3(0.5 \%)$ and $61(15.0 \%)$ respectively and IgG positivities were $66(13.8 \%), 529(91.7 \%)$ and 394 (99.3\%) respectively (Figure 1).

\section{DISCUSSION}

While most of the infections in pregnant women have the same importance with those in non-pregnant women, some infections may cause serious sequelae by transmitting especially in utero during pregnancy or to the baby during delivery. Laboratory findings are very crucial especially if the mother has mild disease or if the symptoms are not clear. ${ }^{[10]}$ Prenatal screening of antibodies produced against infectious agents such as T. gondii, rubella virus and CMV is very crucial. ${ }^{[11]}$

T. gondii is a zoonotic protozoan parasite and its infection prevalence differs around the world according to geographical region, socioeconomic condition and cultural and religious beliefs of the population. ${ }^{[12]}$ Prevalence rates differ between $10 \%$ and $80 \%$ among countries and also differ among different regions in the countries or different societies in the same region. ${ }^{[4]}$ Prevalence rates were reported as $10-30 \%$ in North America, South East Asia, North

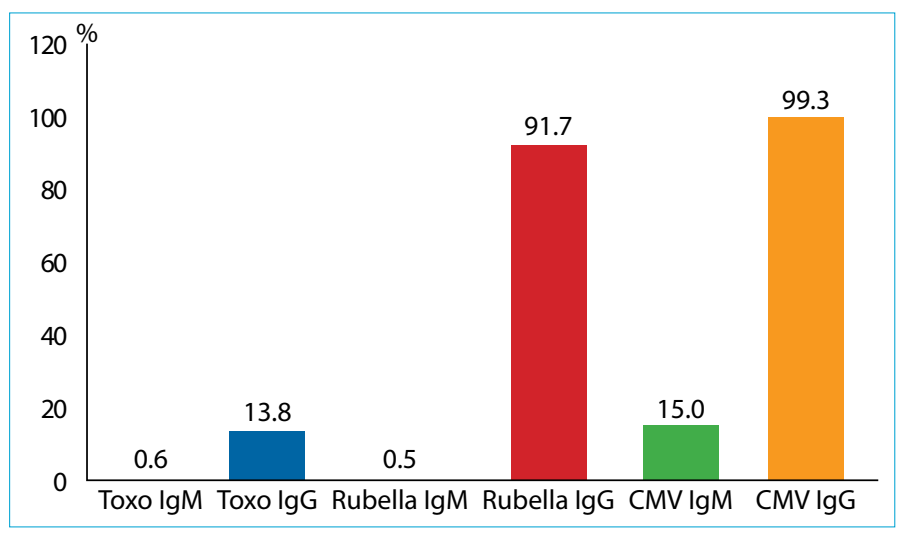

Figure 1. IgM and IgG seropositivity rates of Toxoplasma gondii, Rubella virus, CMV. 
Europe and Sahelian countries of Africa, 30-50\% in Middle and South European countries and higher prevalence rates were reported in Latin American and tropical African countries. $^{[13]}$

In this study, T. Gondii IgM positivity of $0.6 \%$ was found consistent with the data in literature. When the seroprevalence studies on pregnant women in our country were evaluated, it was revealed that the highest seroprevalence rates were in South-eastern and Eastern Anatolia and the lowest rates were in Aegean region (Table 1). ${ }^{[14-27]}$ In this study, T.gondii IgG seropositivity was $13.8 \%$. This rate was found low according to the regional data.

Rubella virus infection is a disease that can be prevented by vaccine. It is crucial because the risk of being infected for fetus is high in active infection of sensitive pregnant women. ${ }^{[28]}$ Rubella virus is held responsible for $2-3 \%$ of congenital anomalies caused by prenatal infection. ${ }^{[29]}$ The distribution of rubella virus is worldwide. It was revealed that the sensitivity rate was between $10 \%$ and $25 \%$ in countries where immunisation efforts for rubella virus

Table 1. IgG seropositivity rates of Toxoplasma gondii, Rubella virus and Cytomegalovirus according to the geographic regions in Turkey

\begin{tabular}{|c|c|c|}
\hline Geographic region & Infections & Seropositivity (\%) \\
\hline \multirow[t]{3}{*}{ Marmara } & Toxo lgG & $23.6-50.0$ \\
\hline & Rubella IgG & 95.7 \\
\hline & CMV IgG & 99.3 \\
\hline \multirow[t]{3}{*}{ Black Sea } & Toxo lgG & $23.7-43.9$ \\
\hline & Rubella IgG & $93.8-98.3$ \\
\hline & CMV IgG & $91.5-99.5$ \\
\hline \multirow[t]{3}{*}{ Aegean } & Toxo lgG & $18.8-37.0$ \\
\hline & Rubella IgG & $89.5-95.1$ \\
\hline & CMV IgG & $90.4-99.0$ \\
\hline \multirow[t]{3}{*}{ Mediterranean } & Toxo lgG & $28.4-57.0$ \\
\hline & Rubella IgG & $93.2-97.5$ \\
\hline & CMV IgG & $93.4-99.3$ \\
\hline \multirow[t]{3}{*}{ Central Anatolia } & Toxo lgG & 26.9-36.9 \\
\hline & Rubella lgG & $92.8-97.3$ \\
\hline & CMV IgG & $98.2-99.8$ \\
\hline \multirow[t]{3}{*}{ Eastern Anatolia } & Toxo lgG & 20.3-63.0 \\
\hline & Rubella IgG & $86.6-96.2$ \\
\hline & CMV IgG & $99.5-100$ \\
\hline \multirow[t]{3}{*}{ Southestern Anatolia } & Toxo lgG & $34.9-68.9$ \\
\hline & Rubella IgG & 94.1 \\
\hline & CMV IgG & 99.2 \\
\hline
\end{tabular}

Toxo IgG: Toxoplasma gondi lgG; CMV IgG:Cytomegalovirus lgG were the least. ${ }^{[30]}$ When the studies on rubella virus seroprevalence in pregnant women in Turkey were evaluated, the lowest rubella IgG positivity with a rate of $86.6 \%$ was in Van and the highest seropositivity with a rate of $97.5 \%$ was in Isparta (Table 1). ${ }^{[14,17,20,22,23,28,31-36]}$ In this study, rubella IgG seropositivity rate which is $91.7 \%$ was a little lower than that of regional data, however, it is consistent with overall data in our country. Our results reveal that there is a rubella virus-responsive pregnant with a rate of $8 \%$. Moreover, rubella IgM positivity was found at a rate of $0.5 \%$ in this study.

While CMV seroprevalence in developed countries is between $42.3 \%$ and $68.3 \%$, this rate is higher in developing countries. ${ }^{[37]}$ In studies on CMV IgG seropositivity rates in pregnant women in Turkey, the rate was generally more than $90 \%$ (Table 1). ${ }^{[1,20-21,23,28,32-35,38-40]}$ In this study, while CMV IgG seropositivity was $99.3 \%$, IgM seropositivity was $14.7 \%$. These results reveal that most of the women of childbearing age face CMV before pregnancy. While single CMV IgM positivity was $0.5 \%$, the rate of positivity was $14.7 \%$ with CMV IgG. These results suggest that most of the congenital CMV infections may be the result of recurring infection in pregnancy.

One of the limitations of the study is retrospective and the other limitation is the different patient numbers for each infection.

\section{CONCLUSION}

As a result, IgM positivity rates for $T$. gondii, rubella virus and CMV were $0.6 \%, 0.5 \%$ and $15.0 \%$ respectively and IgG positivity rates were $13.8 \%, 91.7 \%$ and $99.3 \%$ respectively. The results were consistent with those of regional studies. Seroprevalence studies in pregnant women will be guide for the necessity of prenatal screening tests.

\section{Disclosures}

Peer-review: Externally peer-reviewed.

Conflict of Interest: None declared.

Ethics Committee Approval: This study was performed with the approval of the Non-Interventional Clinical Research Ethical Committee of the University of Health Sciences Gülhane Training and Research Hospital (Approval date: 09.04.2019, Approval number: 2019/19/139).Since this study was retrospective, voluntary consent form could not be obtained.

Authorship Contributions: Concept - H.T.A., A.B.; Design H.T.A., A.B.; Supervision - H.T.A., A.B.; Materials - H.T.A.; Data collection\&/or processing - H.T.A., A.B.; Analysis and/ orinterpretation - H.T.A., A.B.; Literature search - H.T.A.; Writing - H.T.A., A.B.; Critical review -M.G., M.T.Y. 


\section{REFERENCES}

1. Rasti S, Ghasemi FS, Abdoli A, Piroozmand A, Mousavi SG, Fakhrie-Kashan Z. ToRCH "co-infections" are associated with increased risk of abortion in pregnant women. Congenit Anom (Kyoto) 2016;56(2):73-8.

2. Prasoona KR, Srinadh B, Sunitha T, Sujatha M, Deepika ML, Vijaya Lakshmi B, et al. Seroprevalence and Influence of Torch Infections in High Risk Pregnant Women: A Large Study from South India. J Obstet Gynaecol India 2015;65(5):301-9.

3. Boyer SG, Boyer KM. Update on TORCH infections in the newborn infant. NAINR 2004;4(1):70-80.

4. Pappas G, Roussos N, Falagas ME. Toxoplasmosis snapshots: global status of Toxoplasma gondii seroprevalence and implications for pregnancy and congenital toxoplasmosis. Int J Parasitol 2009;39(12):1385-94.

5. Leeper C, Lutzkanin A. Infections During Pregnancy. Prim Care 2018;45(3):567-86.

6. Nyholm JL, Schleiss MR. Prevention of maternal cytomegalovirus infection: current status and future prospects. Int J Womens Health 2010;2:23-35.

7. Margioula-Siarkou C, Kalogiannidis I, Petousis S, Prapa S, Dagklis T, Mamopoulos A, et al. Cytomegalovirus, Toxoplasma gondii and Rubella Vertical Transmission Rates According to Mid-trimester Amniocentesis: A Retrospective Study. Int J Prev Med 2015;6:32.

8. Surpam RB, Kamlakar UP, Khadse R, Qazi M, Jalgaonkar SV. Serological study for TORCH infections in women with bad obstetric history. J Obstet Gynecol India 2006;56(1):41-3.

9. Turbadkar D, Mathur M, Rele M. Seroprevalence of torch infection in bad obstetric history. Indian J Med Microbiol 2003;21(2):108-10.

10. Kourtis AP, Read JS, Jamieson DJ. Pregnancy and infection. N Engl J Med 2014;370(23):2211-8.

11. Tamer GS, Dundar D, Caliskan E. Seroprevalence of Toxoplasma gondii, rubella and cytomegalovirus among pregnant women in western region of Turkey. Clin Invest Med 2009;32(1):E43-7.

12. Singh S, Munawwar A, Rao S, Mehta S, Hazarika NK. Serologic prevalence of Toxoplasma gondii in Indian women of child bearing age and effects of social and environmental factors. PLoS Negl Trop Dis 2014;8(3):e2737.

13. Robert-Gangneux F, Dardé ML. Epidemiology of and diagnostic strategies for toxoplasmosis. Clin Microbiol Rev 2012;25(2):264-96.

14. Kasap B, Öner G, Küçük M, ÖztürkTurhan N, Akın MN, Arıkan S, et al. The Evaluation of Toxoplasmosis, Rubella, Cytomegalovirus and Hepatitis Prevalence of Pregnant Women in Muğla. Tepecik Eğit Hast Derg 2017;27(1):31-6.

15. Duran İ, Nazik S, Nazik H, Duran Ş. Gebelikte Toksoplazma ve Rubella seropozitifliğini değerlendirilmesi. Balikesir Medical Journal 2017;1(1):22-5.

16. Usta A, Hocaoğlu M, Turgut A, Kılınç O, Usta CS, Dalkıran E.
Gebeliğin ilküç ayında rubella ve toxoplazma enfeksiyonlarının taranması. Zeynep Kamil Tip Bülteni 2018;49(1-Ek Sayı):15761

17. Aynioglu A, Aynioglu O, Altunok ES. Seroprevalence of Toxoplasma gondii, rubella and Cytomegalovirus among pregnant females in north-western Turkey. Acta Clin Belg 2015;70(5):321-4.

18. Mumcuoğlu I, Toyran A, Çetin F, Coşkun Alaca F, Baran I, Aksu N, et al. Gebelerde toksoplazmoz seroprevalansının değerlendirilmesi ve bir tanı algoritmasının oluşturulması. Mikrobiyol Bul 2014;48(2):283-91.

19. Akpınar O, Akpınar H. Gebe Kadınlarda Rubella ve Sitomegalovirus Seroprevelansının ELISA yöntemi ile Araştırılması. Balikesir Saglik Bil Derg 2017;6(1):11-5.

20. Obut M, Doğan Y, Bademkıran MH, Akgöl S, Kahveci B, Peker $\mathrm{N}$, et al. Diyarbakır İlindeki Gebe Kadınlarda Toksoplazma, Rubella ve Sitomegalovirus Seroprevalansı. Dicle Med J (2019);46(2):189-94.

21. Kiriş Satılmış Ö, Yapça ÖE, Yapça D, Çatma T. Seroprevalance of Rubella, Cytomegalovirus and Toxoplasma Antibodies Among Pregnant Women that Referred to Sorgun State Hospital. IKSST Derg 2014;6(2):90-6.

22. Karabulut A, Polat $Y$, Türk M, Balci Y. Evaluation of rubella, Toxoplasma gondii, and cytomegalovirus seroprevalences among pregnant women in Denizli province. Turk J Med Sci 2011;41(1):159-64.

23. US SC, Yılmaz Doğru H. Gebelerde Toxoplasma gondii ve Rubella Seroprevalansı: İki Yıllık Değerlendirme. FÜ Sağ Bil Tıp Derg 2018;32(3):119-22.

24. Durdu B, Mutlu M. Sağlıklı Gebelerde Toksoplazma Seroprevelansı ve IgG Avidite Değerlerinin İncelenmesi. Bakırköy Tıp Dergisi 2017;13:140-4.

25. Okyay AG, Karateke A, Yula E, İnci M, Şilfeler DB, Motor VK. Hatay yöresindeki gebelerde toksoplazma iGG seroprevalansi ve avidite testinin taniya katkisi. J Turk Soc Obstet Gynecol 2013;10(3):160-4.

26. Şahin L, Baykuş Y, Deniz R, Yavuz Y, Tazegün Z, Tazegün A, et al. The Investigation of Toxoplasma Gondii Seropositivity in Pregnant Women. J Ann Eu Med 2015;3(3):6-8.

27. Çiçek AÇ, Duygu F, İnakçı İH, Boyar N, Boyar İH. Investigation of Toxoplasma gondii antibodies with ELISA among women of childbearing age in Şanlıurfa province: $A$ three years evaluation. J Clin Exp Invest 2012;3(1):61-5.

28. Kliegman RM, Behrman RE, Jenson HB, Stanton BM. Nelson Textbook of Pediatrics E-Book. Elsevier Health Sciences; 2007.

29. Hinman AR. Rubella and the Americas. Rev Panam Salud Publica/Pan Am J Public Health 2003;14(5):298-9.

30. Gülcen BS, Tüzüner U, Feyzioğlu B, Baykan M. Investigating seropositivitiy of Rubella IgG among women of childbearing age in Konya province. J Turgut Ozal Med Cent 2016;23(4):384-6.

31. Doğan K, Kafkaslı A, Karaman Ü, Atambay M, Karaoğlu L, Ço- 
lak C. Gebelerde Toksoplazma enfeksiyonunun seropozitiflik ve serokonversiyon oranları. Mikrobiol Bul 2012;46(2):290-4.

32. İnci A, Yener C, Güven D. Bir devlet hastanesinde gebe kadınlarda toksoplazma, rubella ve sitomegalovirüs seroprevalansının araştırılması. Pam Med J 2014;7(2):143-6.

33. Altunal LN, Esen AB, Karagöz G, Yaşar K. Seroprevalence of Toxoplasma Gondii, Rubella, and Cytomegalovirus Among Pregnant Refugees and Turkish Women: A Retrospective Comparative Study. South Clin Ist Euras 2018;29(4):235-9.

34. Tanriverdi EÇ, Dikbaş L, Handan A, Kadioğlu BG, Özkurt Z. Antimicrobials. Seroprevalance of Rubella Antibodies Among Pregnant Women in a Regional Maternity Hospital in Eastern Turkey. Mediterr J Infect Microb Antimicrob 2018;7:4.

35. Madendağ Y, Eraslan Şahin M, Çöl Madendağ I, Şahin E, Açmaz G, Müderris ii. Investigation of toxoplasma, cytomegalovirus and rubella seroprevalence in pregnant women admitted to our hospital. Perinat J 2018;26(1):7-10.

36. Bakacak M, Bostancı MS, Köstü B, Ercan Ö, Serin S, Avcı F, et al. Gebelerde Toxoplasma gondii, rubella ve sitomegalovirüs seroprevalansı. Dicle Tıp Dergisi 2014;41(2):326-31.

37. Parlak M, Çim N, Nalça Erdin B, Güven A, Bayram Y, Yıldızhan R. Seroprevalence of Toxoplasma, Rubella, and Cytomegalovirus among pregnant women in Van. Turk J Obstet Gynecol
2015;12(2):79-82.

38. Tekin A, Deveci Ö, Yula E. The seroprevalence of antibodies against Toxoplasma gondii and Rubella virus among childbearing age women in Mardin province. Journal of Clinical and Experimental Investigations 2010;1(2):81-5.

39. Toklu G. Antibodies Frequency Against Toxoplasmosis, Rubella Virus and Cytomegalovirus in Pregnant Women J Clin Anal Med 2013;4(1):38-40.

40. Zhang S, Hu L, Chen J, Xu B, Zhou YH, Hu Y. Cytomegalovirus seroprevalence in pregnant women and association with adverse pregnancy/neonatal outcomes in Jiangsu Province, China. PLoS One 2014;9(9):e107645.

41. Şentürk Ş, Balik G, Şahin FK, Şahin K. Rize Yöresindeki Gebe Kadinlarda Sitomegalovirus Seroprevalansi. Bozok Tıp Derg 2015;5(4)22-6.

42. Efe Ş, Kurdoğlu Z, Korkmaz G. Van yöresindeki gebelerde Sitomegalovirüs, Rubella ve Toksoplazma antikorlarının seroprevalansı. Van Tıp Dergisi 2009;16(1):6-9.

43. Varıcı Balcı FK, Rslan A, Sertöz R, Altuğlu İ. Ege Üniversitesi Tıp Fakültesi Hastanesine başvuran gebelerde rubella ve sitomegalovirüs seroprevalansı. Ege Journal of Medicine 2014;53(4):179-83. 